\title{
PUBLIC SERVICES IN CONSTRUCTION SECTOR AND WASTE MANAGEMENT IN SR
}

\section{VEREJNÉ SLUŽBY V STAVEBNOM SEKTORE A ODPADOVOM HOSPODÁRSTVE V SR}

\author{
Ivana LICHNEROVÁ * - Eleonóra MARIŠOVÁ*
}

\section{Introduction}

The basic definition of public services is that they are services performed in the public interest. This means that individuals, whose role is to provide these services must act in the name of the public interest and abstract from group and individual interests $^{(1)}$. In the conditions of the Slovak Republic, since 2002, in accordance with Act no. 416/2001 Coll. on the transfer of certain powers from the state administration bodies to municipalities and higher territorial units and Act no. 50/1976 Coll. as amended, municipalities are building authorities.

The municipality, among other things, as an independent territorial self-governing and administrative unit of the Slovak Republic, brings together persons who have a permanent resi-

Ivanovič (2014).

\section{Abstract (EN)}

The issue of public interest is regulated by the legislation of the Slovak Republic, which addresses services provided in the public interest in specific fields. One of these areas is also the provision of services in the construction sector, while these competencies were transferred by the Act no. 416/2001 Coll. from the state administration to self-government - municipalities and each municipality became a building authority. The problem, however, is that mostly small building offices have existential problems with the performance of this delegated competence, as the basis of their existence - financial resources for this competence- are insufficient. The way out of this unfavourable situation in this case could be the adoption of new legislation consisting of legally defined seats of joint building offices. When investigating the construction competencies of municipalities, we also encounter a solution for waste management (since it is also one of the competencies transferred to municipalities, but only partially). Municipalities are burdened by insufficient legislative specification of sorting biodegradable municipal waste from mixed municipal waste and subsequently an alternative in practice - waste sorting by citizens themselves. The population is dissatisfied with the amount of the fee for the collection and removal of municipal and small construction waste. In order to avoid paying fees for the storage of small construction waste, municipal residents export it to black dumps, which is in conflict with the EU and Slovak legislation in the field of waste management, whereas this type of waste can be the basic material for new, especially construction, materials.

\section{Keywords (EN)}

transferred competences, construction competence, waste, public interest

\footnotetext{
Slovak University of Agriculture in Nitra
}

dence in its territory and take care of their needs when exercising self-government. ${ }^{(2)}$

This was due to the process of decentralization of public administration and due to the adoption of the Act no. 416/2001 Coll. on the transfer of certain powers from the state administration bodies to municipalities and self-governing regions. „Process of decentralization was and constantly is an immanent part of public administration reform. Decentralization signifies transfer of competences and responsibilities from central to lower (autonomous) level of government".(3)

In Slovakia "The conception of decentralization and modernization of public administration" was approved for the period 2000-2004 in which more than 300 competences were

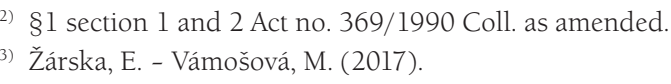

\section{Abstrakt (SK)}

Problematika verejného záujmu je upravená legislatívou Slovenskej republiky, ktorá rieši služby poskytované vo verejnom záujme v špecifických oblastiach. Jednou z týchto oblastí je aj poskytovanie služieb v stavebnom sektore, pričom tieto kompetencie boli prenesené zákonom č. 416/2001 Z.z zo štátnej správy na samosprávu (obce) a každá obec sa stala stavebným úradom. Problémom však je, že prevažne malé stavebné úrady majú existenčné problémy pri výkone tejto prenesenej kompetencie, nakolko základ ich existencie - finančné zdroje na výkon kompetenciesú nepostačujúce. Východisko z tejto nepriaznivej situácie by v tomto prípade mohlo nastat prijatím novej legislatívy pozostávajúcej zo zákonom definovaných sídiel spoločných stavebných úradov. Pri výkone stavebných kompetencií obcí sa stretávame aj s riešením nakladania s odpadmi (taktiež ako jednou z prenesených kompetencií na obce, avšak len čiastočne). Obce sú zatažené nedostatočnou legislatívnou špecifikáciou vytriedovania biologicky rozložitelného komunálneho odpadu od zmesového komunálneho odpadu a následne alternatívou v praxi - triedenia odpadu samotnými občanmi. Obyvatel'stvo je nespokojné s výškou poplatku za zber a odvoz komunálneho a drobného stavebného odpadu. Aby obyvatelia obcí predišli plateniu poplatkov za uskladnenie drobného stavebného odpadu, vyvážajú ho na čierne skládky, čo je v rozpore s legislatívou EU a SR v oblasti nakladania s odpadmi, pričom tento druh odpadu môže byt' základným materiálom pre tvorbu nových, najmä stavebných materiálov.

\section{Kl'účové slová (SK)}

prenesené kompetencie, stavebná kompetencia, odpad, verejný záujem 
planned for transfer from local state governments (regional and district offices) to regional and local self-governments. ${ }^{(4)}$

In addition to the transfer of competence in the area of building regulations from the state bodies to self-governing units, the competence in the area of waste management - municipal waste and small construction waste - was also transferred. Municipal waste can be defined as the total amount of used materials originating from households and smaller local businesses, where collection is provided by the local self-government ${ }^{(5)}$. Waste is a necessary amount of materials that arise from people's lives and the performance of their economic activities ${ }^{(6)}$. Most of the waste produced is recycled or landfilled, where it is decomposed for decades or even centuries.

In Slovakia, competence in waste management and building regulations is provided both by municipalities as self-governing units (as delegated competence) and by district authorities as part of state administration. The exercise of competence in the area of construction regulations or waste management improves the quality of life of the inhabitants of each municipality. It should also be noted that in terms of the management of construction waste generated during construction, these competencies are interlinked. It can be stated that these are services of general interest to citizens, which are performed in the public interest.

In Slovakia, however, we are currently in a situation where "the smaller the municipality, the greater the problems with securing the transferred competencies". ${ }^{(7)}$

In the paper, we point out the issues associated with the exercise of competence in the field of construction regulations and waste management (including small construction waste), which are performed for the population in accordance with the aforementioned public interest.

\section{Objective and Methodology}

The main objective of the presented paper is to point out, by using the domestic sources, the exercise of competencies in the field of building regulations and waste management in terms of the public interest in the conditions of the Slovak Republic with emphasis on the EU legislation. In the Slovak Republic, the management of municipal waste and small construction waste, which is generated in the municipality is the responsibility of the municipality, in accordance with the Act no. 369/1990 Coll. as amended. According to Act no. 582/2004 Coll. on local taxes and local fees for municipal waste and small construction waste, as amended, the fees apply to natural and legal persons, who have a residence/registered office in the territorial district of the municipality.

Competence in the area of building regulations is regulated in accordance with the Act no. 50/1976 Coll. as amended and financing is regulated by the Act no. 523/2004 Coll. as amended. Through the process of decentralization of public administration, the state is fully committed to financing all costs that will arise with the exercise of competence in the field of build-

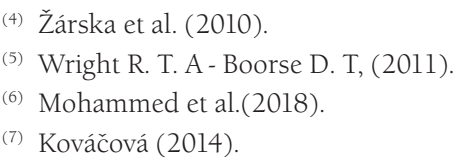

ing regulations.

The main goal is followed by the secondary goals, which are:

- analysis of problems that arise for municipalities in the exercise of competence in the field of building regulations through conducted controlled interviews with representatives of a sample of municipalities in the Slovak Republic,

- analysis of problems that arise for municipalities in the exercise of competence in the field of waste management on the basis of controlled interviews with PZO Nitra (Ponitrianska Association of Municipalities Nitra),

- pointing out the method for obtaining funds for the exercise of competence in the field of building regulations and waste

The main and secondary objectives of the paper are fulfilled through the analysis of the EU legislation, valid legal norms of the Slovak Republic and through the analysis of domestic and foreign sources.

We defined the specific secondary goals related to the problems of municipalities that arise in the exercise of competence in the field of building regulations through guided interviews conducted with employees of a sample of municipalities (building authorities) located within the Nitra Region. Problems that arise for municipalities in waste management were identified through the PZO Nitra, also within the municipalities of the Nitra Region.

\section{Suggestion for solutions for the problems identified during the research}

Through the process of reform - decentralization of public administration- in Slovakia there were a large number of changes related to the performance of public services.

Citizens expected the reform to bring changes to the management of public affairs, specifically they expected high quality level and higher speed in management of public affairs without unnecessary bureaucracy. As an example, many set the ideal situation the one in the Western European countries where there was a shift from "govern to governance".

One of the burning problems that the administration of public affairs in Slovakia has to deal with is the area of municipal waste and construction proceedings. These are the two most problematic and criticized areas.

Via the mentioned reform in Slovakia, more than 300 competencies originally exercised by state authorities were transferred to municipalities/self-governing units ${ }^{(8)}$.

Among the competencies, one of the most problematic, when it comes to its provision, is also included, namely the competence in the area of building regulations. Naturally, many other competencies are directly or indirectly related to it, for example the competence of waste management - municipal waste and also small construction waste.

The Slovak Republic has currently 2927 municipalities $^{(9)}$. All these municipalities are obliged, in terms of the public inter-

\footnotetext{
(8) Leško, (2015).

(9) Bačík, (2020).
} 
est, to perform services for the population, society - building regulations, as well as waste management. In accordance with the Building Act no. 50/1976 Coll. as amended and Act no. 79/5015 Coll. on waste, as amended, all inhabitants are entitled to such services within the given provision. Public services associated with the exercise of these competencies are regulated by legal norms, which public authorities and residents are obliged to respect. In the introduction of the paper, we mentioned that problems often arise in the exercise of delegated competencies to municipalities.

Based on our previous analyses and studies ${ }^{(10)}$ concerning the exercise of competence in the area of building regulations, we have stated that municipalities identified the problem of financial underdimensioning for the provision of transferred competencies. To provide their competence in the area of building regulations, municipalities have obtained only limited financial resources provided by the state. These resources have been recalculated per capita.

As an example, we present the municipality, which had a population of $7^{(11)}$ inhabitants as of 31 December 2018 (the municipality Príkra) and received $7,77 €^{(12)}$ from the state budget for 2019. On the other hand, the municipality Smižany, which had population of $8698^{(13)}$ as of 31 December 2018, received for the year 2019 the sum of $9654,78 €^{(14)}$. The amount of the subsidy was recalculated for the relevant year by a coefficient of $1,11 €$ per capita in accordance with the Decree of the Ministry of Transport, Construction and Regional Development of the Slovak Republic of 21 December 2010 no. 20786/2010-SRVS/z.54145-M on the provision of subsidies from the state budget to municipalities to cover the costs of the delegated performance of state administration in the field of building regulations. Without further inspection, it is already possible to conclude that the municipality of Príkra did not have sufficient financial resources to exercise its competence in the area of building regulations. In the event that no construction activity or administration related to the performance of construction competence was registered within the year, it was still necessary for the municipality to have a qualified employee to perform the competence, to whom it was necessary to pay the minimum wage costs.

An employee in public administration is a person who performs his/her work activity in the public interest and is remunerated in accordance with the applicable salary scales for the performance of work in the public interest. These salary tariffs are regulated by legislation ${ }^{(15)}$.

Specifically, an employee of the building authority falls into the 8 th or 9 th grade, which means that his monthly salary should range from $887 €$ to $1167 €$ per month (for $100 \%$ work-

\footnotetext{
(10) Marišová - Lichnerová (2019); Lichnerová (2019).

(11) E-obce (2020) - https://www.e-obce.sk/obec/prikra/prikra.html.

(12) Ministry of transportation of the SR (2019). https://www.mindop.sk/uploads/extfiles/dotacie/2019/Rozpis_dotacie_na_PVSS_ SP_a_dopravy_2019.pdf.

(13) E-obce (2020) - https://www.e-obce.sk/obec/smizany/smizany. html.

(14) Ministry of transportation of the SR (2019) https://www.mindop.sk/uploads/extfiles/dotacie/2019/Rozpis_dotacie_na_PVSS_ SP_a_dopravy_2019.pdf.

(15) Annex no. 3 to the Government regulation no. 388/2018 Coll.
}

ing hours, depending on the number of years of experience).

Although the state guarantees full financing of competences in the field of building regulations ${ }^{(16)}$ in terms of budgetary rules of public administration ${ }^{(17)}$ - this is impossible to maintain in practice. Municipalities must pay extra for the exercise of competence in the area of building regulations, which appears to be illegal ${ }^{(18)}$. Municipalities in Slovakia solve this problem through possible contractual cooperation between municipalities on a voluntary basis ${ }^{(19)}$.

On the other hand, if we want to compare the Slovak Republic in the exercise of competence in the field of building regulations with the situation in other European countries, we must state that many of them have cooperation between municipalities for the exercise of competence in the field of building regulations (but also others) determined by legislation. As an example, we mention the neighbouring Czech Republic, which adopted a law on the designation of municipalities with extended powers and an authorized municipal office, which precisely determines the seats of municipalities that exercise competence in the building authority for a group of other municipalities.

Developed countries have a much more coordinated, interconnected and more comprehensive understanding of this area. Another example is Austria, where municipalities may associate for the purpose of cooperation within a province (in order to respect the correct division of the country). In Germany, the conditions are defined by the federal state. In Lower Saxony, municipalities with a population of less than 400 have an obligation to associate, the maximum number of municipalities in one association is 10 and the population of the association may not exceed 7000 . France, which is considered a highly fragmented state (currently has 36000 municipalities), has ensured by law that not all municipalities have the same competencies. Their implementation was divided by legislation into three forms of community of municipalities, namely: municipal communities, agglomeration communities and urban communities. In order for each community to function, it must meet the conditions prescribed by law. In France, these statutory forms of inter-municipal cooperation are very popular, as their existence results in a reduction in the number of disadvantages of a fragmented municipal structure ${ }^{(20)}$.

Municipalities in Slovakia do not merge for the purpose of implementing construction competencies, but conclude contracts on the exercise of construction competencies by joint building authorities pursuant to Section 20 of Act no. 369/1990 Coll. on municipal establishment as amended. Nevertheless, there are still municipalities in the territory of the Slovak Republic that exercise competence in the area of building regulations independently, but these are mostly large municipalities (such as the already mentioned municipality of Smižany).

\footnotetext{
(16) Act no. 369/1990 Coll. on municipal establishment as amended and Act no. 416/2001 Coll as amended, Report on the control activities of the Supreme Audit Office for the year 2015

(17) Act no. 523/2004 Coll. on budgetary rules in public administration as amended.

(18) Act no. 369/1990 Coll. as amended.

(19) \$20 Act no. 369/1990 Coll. as amended.

(20) Klimovský (2011).
} 


\section{$\underset{\text { Aggrárne }}{\underset{\text { právo Eư }}{2}}$

Table 1: Local fees for municipal waste and small construction waste in town Nitra

\begin{tabular}{|l|l|c|c|}
\hline & Indicator & \multicolumn{2}{|c|}{ Fee rate } \\
\cline { 2 - 4 } & & YEAR 2019 & YEAR 2020 \\
\hline 1. & $\begin{array}{l}\text { Rate of fee for municipal waste per person and calendar year for entities for which quantitative } \\
\text { collection of municipal waste is not introduced }\end{array}$ & $0,0685 €$ & $0,081973 €$ \\
\hline 2. & $\begin{array}{l}\text { Fee rate for l litre of municipal waste (for entities for which quantitative collection of municipal } \\
\text { waste is introduced) }\end{array}$ & $0,012 €$ & $0,02 €$ \\
\hline 3. & Fee rate per l kilogram of small construction waste without pollutants & $0,05 €$ & $0,05 €$ \\
\hline
\end{tabular}

Source: Generally binding regulation of the city of Nitra no. 11/2014 (as amended by Appendices 1, 2 and 3) on the local fee for municipal waste and small construction waste

In addition to the mentioned financial problem, our goal was, also through qualitative research carried out on a sample of municipalities located within the Nitra Region, to identify other problems that arise in the area. We carried out qualitative research through guided interviews with employees of the building authorities of the Nitra Region. Specifically, there are 354 municipalities (building authorities) located in the Nitra Region. The conducted interviews covered $89,19 \%$ of their total number. The responses of employees, who commented on the problems of their building authorities generally followed the problem of financing. They were unequivocally of the opinion that the building authorities were staffed by a staff base with insufficient qualification where they would welcome minimal legal training. Building authorities would need new staff, as legislation and "bureaucracy" require more and more work and competence-related activities. Here, however, the building authorities encounter the reluctance of new potential employees to perform this activity for a relatively low financial reward. Overall, however, it must be stated that even though the building authorities need new qualified staff, they still cannot recruit them, even if they have them at their disposal. The reason is that they are unable to provide them with adequate pay.

In the Slovak Republic for the management of municipal waste and small construction waste, which is generated in the municipality, in accordance with Act no. 369/1990 Coll. as amended, is the responsibility of the municipality. According to Act no. 582/2004 Coll. on local taxes and local fees for municipal waste and small construction waste, as amended, the fees apply to the natural and legal persons who have a residence/registered office in the territorial district of the municipality. The revenue from the local fee for municipal waste and small construction waste will be used by the municipality exclusively for the collection, transport, recovery and disposal of municipal waste and small construction waste.

The EU waste framework directive is the Directive 2008/98 /EC of the European Parliament and of the Council of 19 November 2008 on waste. According to this directive in its consolidated version, each EU Member State must have a waste management program and a waste prevention program in place. In the Strategy of the Environmental Policy of the Slovak Republic until 2030, the Government of the Slovak Republic defined the goal of achieving a better quality of the environment and a sustainable circular economy using as few non-renewable natural resources and dangerous toxic substances as possible. Based on internationally comparable indicators that measure the level of results achieved in individual areas of the environ- ment, Slovakia lags behind developed countries most in waste management and air quality. The recycling rate of municipal waste is one of the lowest in the EU, while landfilling is still the dominant form of waste management and its rate is one of the highest in the EU 21.

The basic vision of the Strategy of the Environmental Policy of the Slovak Republic until 2030 is to achieve a better quality of the environment and a sustainable circular economy using the least possible non-renewable natural resources and dangerous toxic substances.

All entities in Slovakia must gradually increase the level of waste sorting, thus supporting the circular economy. The circular economy (CE) differs from the "unsustainable" traditional economy by introducing a cyclical flow model. CE is a regenerative system that focuses on the elimination of waste through closing loops and reduces the volume of waste produced, which would otherwise end up in landfills and subsequently in incinerators.

Directive (EU) 2018/852 of the European Parliament and of the Council further requires Member States to ensure that they take further precautionary measures to prevent the generation of packaging waste and to minimize the environmental impact of packaging. According to this Directive, Member States are required to bring into force the laws, regulations and administrative provisions necessary to comply with this Directive by 5 July 2020. The Slovak Republic has implemented this obligation, but it must not be forgotten that the Slovak Republic still lags far behind developed countries with waste and air quality. The recycling rate of municipal waste is one of the lowest in the EU, while landfilling is still the dominant form of waste management and its rate is one of the highest in the EU.

The Vision and Development Strategy of the Slovak Republic 2030 is currently being prepared, which introduces integrated strategic management and planning at all levels of public administration, which significantly contributes to reducing the negative impacts of the political cycle and ensuring continuity in implementing strategic programs and projects in the Slovak Republic. This circular economy strategy outlines several waste targets, namely increasing the sorting and recycling rate of waste to $65 \%$ and reducing landfilling to a maximum of $10 \%$ of the total volume.

In the Waste Management Program of the Slovak Republic for the years 2016 - 2020, the concept of circular management is included in waste recycling. It focuses in particular on limiting the landfilling of municipal and industrial biodegradable waste. Its strategic goals are: a significant reduction in the amount of municipal biodegradable waste deposited in 
landfills and an increase in the recovery of waste material and energy.

Regarding the problems related to waste in the Slovak Republic, we can say that people are primarily bothered by the ever-increasing price for fees related to the collection of municipal waste and its disposal in landfills. As an example, we mention the local fee of the city of Nitra for municipal waste and small construction waste comparison of 2019 and 2020 (see Tab. 1). (21)

In the previous calendar year (2019), but also in the years before, the inhabitants of the town paid an annual bill for 1 person in the amount of $25 €$. For the current year (2020), this amount has been increased to $30 € /$ person. Citizens over the age of 72 paid $50 \%$ less of the price per year. However, based on the current situation, it should be noted that the Municipal Office in Nitra is already considering increasing the fee for municipal waste disposal (bills of lading per person) in 2021 from the current $0,081973 €$ to the planned $0,10137 €$. In total, the annual fee will be increased from $30 €$ to $37 €$ per person. The reason for the future increase will be the fact that the revenues from the waste fee need to cover the total cost of the city for this competence, otherwise there would be a violation of the law.

"The Supreme Audit Office stated in its report as early as 2018 that most municipalities finance waste from their own budgets, even though this activity is to be covered by the revenue from the local fee under the Waste Act."(22)

Reducing current and future waste prices would be possible with a higher separation rate than before, even though waste sorting works in the city. Unfortunately, in many examples, citizens do not have the required number of waste bins, which would be adequate for the ever-increasing amount of waste production. However, the company often encounters the problem of incorrect waste sorting. Here we also encounter the opinion that individual labelling of products does not contain information about its composition and therefore people do not know how to classify the "packaging" (when separating) - labelling on the packaging is unfortunately not mandatory.

Through qualitative research carried out in the Ponitrianska Association of Municipalities for Separate Waste Collection and Management (PAM), which is an interest association of legal persons and it unites 57 municipalities in the Nitra Region, we found that municipalities through PAM implement:

- ensuring the collection, transport and disposal of unsorted municipal waste

- sorting of municipal waste and building composting plants,

- solving problem phenomena in waste management in municipalities that are members of the association.

The problems that we identified in the conducted interviews with the representatives of the municipalities associated in the PAM and the representatives of the PAM are following:

1. insufficient processing capacity, as collection companies are forced to collect waste, but after sorting the sales are failing- they see the solution in the support of domestic processors,

(21) Generally binding regulation of the city of Nitra no. 11/2014 (as amended by Appendices 1, 2 and 3).

(22) Final Report - The Supreme Audit Office of the SR (2018).
2. currently, separate collection in Slovakia is financed by the producer responsibility organizations (PRO), with which the collection companies or municipalities agree on prices, but it happens that PRO refuses the collection company full reimbursement of costs, even though Slovak legislation imposes it on them,

3. in Slovakia, the consumption capacities for sorted raw materials are not sufficiently built, which results in a rapid decrease in their value and this has a negative impact on the management of collection companies,

4. the legislation of the Slovak Republic does not specify who will sort biodegradable municipal waste from mixed municipal waste, whether it will be sorted on sorting lines or this obligation will be taken over by the municipality in the form of waste sorting by the citizens themselves.

Another problem we have identified is that in every municipality it is not possible for residents to separate all types of waste. In this context, municipalities incur additional costs, as if municipalities want to separate such waste, they have to transfer it to another municipality that separates it. They must then pay the employee who transport such waste, as well as the treatment itself. This is also confirmed by the Supreme Audit Office Report $^{(23)}$

When dealing with small construction waste, which is a product of construction activities related to construction competence, it is necessary to comply with Act no. 79/2015 Coll. on waste as amended. This is waste from routine maintenance work ${ }^{(24)}$ performed by or for a natural person, this waste is a subject to the fee for municipal waste and small construction waste. The issue of disposal of construction waste and the possibility of its further use is gradually becoming one of the priority topics in the current effort to create a long-term sustainable development of environmental policy. Small construction waste can be used after its separation for further processing. This can be, for example, filling for engineering network backfills, embankment material for roads, filling for concrete, production of brick concrete or other building materials (of course depending on their technical standards).

In terms of the issue of storage of small construction waste in Slovakia, we often encounter the emergence of the so-called "black (illegal) dumps". According to our analysis, the reason for the creation of such landfills is mainly the amount of fee for the storage of small construction waste in a "legal landfill". However, these "black dumps" arise not only from small construction waste but also from municipal waste. This is an incomprehensible situation where residents arbitrarily throw waste into nature, even though the law prohibits such conduct. If such action is discovered by another person, e.g. within the city of Nitra, the detected event must be reported to the relevant District Office - Department of the Environment, whose duty is to investigate the situation and to investigate whether the extent of the "black dump" corresponds to a crime against the environment.

A person, a municipality, or, depending on the type of waste, a city or a competent body of the state administration of waste

\footnotetext{
(23) Final Report - Supreme Audit Office SR 2018.

(24) $\S 80$ section. 5 Act no. 79/2015 Coll. on waste as amended.
} 
management must ensure the disposal or recovery of waste in accordance with the law at its own expense. Prevention against "black dumps" can be done in form of photo traps, regular inspections or the creation of resting areas around the area where irresponsible residents tend to dump waste illegally.

Regarding construction activities in Slovakia and the exercise of competence in the field of building regulations, it is possible to emphasize the plan of the current Government, which was published through its program statement for the period 2020-2024. The Government of the Slovak Republic is planning structural changes in public administration in the construction sector, strengthening the importance of spatial planning and abolishing building authorities as self-governing units. From the point of view of the above, the competence in the area of the building regulations would again pass under the state administration bodies, whereby the municipalities would lose control over the exercise of this competence. According to the Government of the Slovak Republic, the abolition of building authorities will strengthen the position of specialized district offices when analysing the influences and interests of participating actors and strengthening the position of the Slovak Building Inspectorate in construction control and decision-making in conflict proceedings.

In the case of waste, the Government of the Slovak Republic will support international cooperation in the field of combating environmental crime and illegal activities related to waste. The Government of the Slovak Republic will strive to ensure that the basic penalty for those who create an illegal landfill is to return the affected site to its original condition at its own expense within a specified period ${ }^{(25)}$.

\section{Conclusions}

In its Program Statement for the years 2020-2024, the Government of the Slovak Republic is planning many changes in the performance of public services. In terms of the competencies we. analysed, namely competencies in the field of building regulations and waste, the following is planned: in the construction sector, strengthening the importance of spatial planning and abolition of building offices - this assumes strengthening the position of district offices as offices to which competencies will be transferred ; in the case of waste, the Government of the Slovak Republic will support international cooperation in the field of combating environmental crime and illegal activities related to waste. The Government of the Slovak Republic will also strive to ensure that the basic punishment for those who create an illegal landfill is to return the affected site to its original condition at its own expense within a specified period.

At present, the dilemma is whether the intentions of the current government within the exercise of competence in the area of building regulations will contribute to a more effective exercise of the competence. From a practical point of view, this would mean that 2927 municipalities in the Slovak Republic will cease to exercise construction competence and they will be exercised by 72 district offices according to Act no. 180/2013 Coll. on the organization of local government as amended.

(25) Program Statement of the Government of the Slovak Republic 2020-2024, part Environmental crime
Our opinion is that this question should be answered only after a more detailed analysis of all the advantages and disadvantages associated with the future of building competence in accordance with the Program Statement of the Government of the Slovak Republic for 2020-2024. In contrast, we would emphasize that the exercise of the competence in the field of building regulations could be carried out in the territory of the Slovak Republic even after the example of the Czech Republic or France. It means cooperation between municipalities in the exercise of competence in the field of building regulations (in the future also other competencies), while these municipalities would be precisely determined by legislation.

In the case of waste management, we consider the intention of the Slovak Government to be realistic in the context of further development. The problems and ambiguities of municipalities in the case of waste management and especially in case of fees associated with waste could be solved by increasing the share of waste separation, but especially by the subsequent technical and material provision of the implementation of this activity.

\section{References}

1. BAČÍK, V. 2020. Slovenská republika - sumárne údaje. Bratislava: UK. Available online: http://www.sodbtn.sk/obce/index_kraje. php.

2. IVANIČ, D. 2014. Etika vo verejnej službe a verejný záujem. Banská Bystrica. Motus in verbo. III/2. 72 p. ISSN 1339-0392. Available online: http://invenio.webdepozit.sk/record/518/ files/1339-0392(201411)03_02.pdf\#page=10.

3. KLIMOVSKÝ, D. 2011. Samosprávy v EÚ - FRANCÚZSKO, 1. čast'. Košice: TUKE - Územná samospráva. 58-62 p. Available online: http://www3.ekf.tuke.sk/krvam/files/clanky/klimovsky/ klimovsky_31.pdf.

4. KOVÁČOVÁ, E. 2014. Teória a prax verejnej správy v podmienkach Slovenskej republiky. Banská Bystrica: Univerzita Mateja Bela. 236 p. ISBN 978-80-557-0725-8.

5. LEŠKO, D. (2015). Formation of regional level of self-government int he process of transformation in Slovakia. In: Journal for universal excellence. September 2015, Vol. 4. Issue 3, p. A1All. [Online]. Available: https://www.fos-unm.si/media/pdf/ RUO/2015\%203/8.pdf.

6. LICHNEROVÁ, I. 2019. Financial and personal issues of the transferred state administration competencies in the building procedure to municipality offices. In Acta regionalia et environmentalica. 16, 2 (2019), s. 45--52. ISSN 1336-5452.

7. MARIŠOVÁ, E. -- LICHNEROVÁ, I. (2019). Contractual cooperation of municipalities for performance of transferred competencies in the building sector: Zmluvná spolupráca obcí na zabezpečovanie výkonu prenesených kompetencií na samosprávu v stavebnom sektore. In EU agrarian Law. 8, 2 (2019), s. $27--36$. ISSN 1339-9276.

8. MOHAMMED M., DONKOR A., OZBAY I. (2018). Bio-Drying of Biodegradable Waste for Use as Solid Fuel: A Sustainable Approach for Green Waste Management. In intechopen.com [online]. (C2020 [cit.2020-03-02]. Available online: https://www. intechopen.com/books/agricultural-waste-and-residues/biodrying-of-biodegradable-waste-for-use-as-solid-fuel-a-sustainable-approach-for-green-waste-manag.

9. SUPREME AUDIT OFFICE OF THE SR. (2018). Efektívnost a účinnost triedeného zberu komunálneho odpadu. Banská Bystrica. Available online: https://www.nku.gov.sk/documents/10157/265201/96466--110.pdf. 
10. ŽÁRSKA, E. et al. 2010. Public Administration I, Bratislava: Ekonóm. 176 p., 2010.

11. ŽÁRSKA, E. - VÁMOŠOVÁ, M. (2017). DECENTRALIZATION ANDADMINISTRATIVE CAPACITY OF MUNICIPALITIES. Kurdějov. XX. mezinárodní kolokvium o regionálních vědách. 977 p. DOI: 10.5817/CZ.MUNI.P210-8587-2017-115.

12. WRIGHT, R. T., BOORSE D. F., (2011) Environmental science Toward a Sustainable Future, San Francisco: Pearson Education, s. 545 - 587. ISBN 978-0-321-70140-4

\section{Contact address/ Kontaktná adresa}

prof. JUDr. Eleonóra Marišová, PhD.

Slovak University of Agriculture in Nitra,

Faculty of European Studies and Regional Development, Department of Law, Tr. A. Hlinku 2, 94976 Nitra

e-mail: eleonora.marisova@uniag.sk

\section{Ing. Ivana Lichnerová}

Slovak University of Agriculture in Nitra,

Faculty of European Studies and Regional Development,

Department of Law, Tr. A. Hlinku 2, 94976 Nitra,

e-mail: xlichnerovai@is.uniag.sk 